\title{
Accounting for Power and Resistance: the University of Ferrara under the Fascist Regime in Italy
}

\begin{abstract}
Recognising the dynamic character of the exercise of power, this study analyses the complex interplay between power and resistance, as conceived by Foucault, after the Italian Fascists sought to subjugate all Italian universities. When the University of Ferrara, a 'Free University', resisted the government's intentions, which would also have meant restricting access to higher education to working class youth, accounting practices became essential in providing justification for the government's actions. In response, the University was forced to use accounting practices as its main form of defence. This resulted in the government having to use different tactics to achieve its final goals. If resistance is met by governments in the implementation of their programmes this may require a shift in the tactics originally employed to achieve the planned outcomes. Greater demands were placed on the funders of the University and changes were made to how the University's performance was represented, interpreted and evaluated by the means of accounting practices. In the power struggle, accounting played different roles in the service of conflicting objectives, ranging from concealing the interested nature of political action, demonstrating the achievement of financial stability and self-sufficiency, providing legitimacy or ensuring the use of resources consistent with the aims of those who exercised power. So persuasive was the action enabled by accounting information that the State was finally able to gain control of the University without making it a 'Kingdom University', and hence seeming to preserve the appearance of independence almost until the end of the Fascist regime.
\end{abstract}




\section{Introduction}

After the conquest of power in 1922 Italian Fascists quickly sought greater control of universities and other educational institutions to gain the committed allegiance of future generations to the vision and goals of the regime (Giuntella, 1992). This was part of a wider reform of Italian education promoted in 1923 by Giovanni Gentile ${ }^{1}$, the newly appointed Minister of Education. The Fascists focussed their efforts initially on a renowned university, the University of Ferrara ${ }^{2}$ (hereafter the University), which since its formation in 1391 had been very protective of its independence (Cazzetta, 2004; Pepe, 2003; Madonna, Maran \& Cestari, 2014). The University of Ferrara was the first in the Italian territory to become a Free University on $14^{\text {th }}$ February 1860 when an important distinction was made in the Kingdom of Sardinia between 'Regie Università' (Kingdom Universities) and 'Libere Università' (Free Universities) ${ }^{3}$. Kingdom Universities were managed and funded by the government while Free Universities were

\footnotetext{
${ }^{1}$ Giovanni Gentile taught philosophy and held managerial positions in various Italian universities and edited the first edition of the Italian Encyclopaedia. In his political career, he served as Minister of Education between 1922 and 1924 in Mussolini's first government and was a member of a commission appointed by Mussolini to review the Italian Constitution. He is considered the main ideologist of Fascism, although his ideas matured well before the advent of organised Fascism. His work markedly influenced Mussolini's policies for it provided not only a philosophical basis for the regime but also a set of guiding principles (Gregor, 1974).

2 The University of Ferrara has been the focus of a study by Madonna, Maran and Cestari (2014) who investigated the role of accounting in the relationship of the University with the Papal State following reforms enacted in 1771 and 1824.

${ }^{3}$ Ferrara's example was then followed by another three universities, namely Perugia $\left(16^{\text {th }}\right.$ December 1860), Camerino (24 ${ }^{\text {th }}$ January 1861) and Urbino (23 $3^{\text {rd }}$ October 1862). The Catholic University of the Sacred Heart was established in Milan on $24^{\text {th }}$ June 1920 and then officially recognised as a Free University by the Fascist State in 1924. Nevertheless, being a private institution supported by the Roman Catholic Church it was less exposed to financial issues than the public Free Universities.
} 
effectively self-funding universities. The Fascists believed that submission of the most renowned Free University in the country would provide the means to set a strong example of their determination to gain complete control of the Italian higher education system. When the University resisted the attempt to control it, the Fascists sought to undermine the financial independence of the University by employing a number of tactics which relied upon accounting practices.

Recognising the call by Baños et al. (2005) to study accounting under different political contexts, the study highlights the shifting roles of accounting when it was used by the Fascists after their rise to power in their attempts to achieve control of a key social and cultural institution, the University of Ferrara, which traditionally had resisted efforts to exert influence over it. The manner in which accounting practices have the potential to create and maintain relations of power between different individuals and institutions has been given particular emphasis by Foucauldian studies in the accounting literature (Sargiacomo, 2008; Baños et al., 2005; Bigoni \& Funnell, 2015; Neu \& Heincke, 2004; Maran, Bracci \& Funnell, 2015; Yayla, 2011; Funnell et al., 2017). However, less attention has been given to the possibility and nature of resistance with the exercise of power (Kosmala \& McKernan, 2011; Ezzamel, 1994; Andrew \& Cahill, 2017; McPhail, 1999; Baños, Domínguez \& Gutiérrez, 2016). According to Foucault (1978, 1982, 2007, 2008), the existence of a power relationship implies the presence of resistance because 
the exercise of power will be confronted by other forms of power which seek to reach different goals.

The enactment of a governmental plan very often will be confronted with resistance, requiring a re-focusing of the tactics employed to implement the plan. This recognises that power has a dynamic character derived from a "process which, through ceaseless struggles and confrontations, transforms, strengthens, or reverses [force relations]" (Foucault, 1978, p. 92). As a result, the enactment of a government programme and the related role of accounting need to be understood as a process of change (Baños, Domínguez \& Gutiérrez, 2016). In this process power and resistance interact and outcomes are not the uncontentious result of the enactment of the will of those who hold the supreme authority within a society. Consequently, accounting can play different roles in the unravelling of a power relation, navigating between the aims for which it is mobilised and the related response from those on whom power is exercised.

The study adds to the existing literature by considering an under-researched context, that of Italian Fascism which, despite the calamitous influence that it had in the $20^{\text {th }}$ century, has received little attention in the accounting literature (Cinquini, Giannetti \& Tenucci, 2016, p. 446). In the context of Fascism, Cinquini $(2005 ; 2007)$ has examined the influence of the totalitarian State on the practice of accounting and business 
education, while Cinquini, Giannetti and Tenucci (2016) explored the interplay between the Fascist government, Germany, academics and enterprises in the development of costing techniques. In another study, Sargiacomo et al. (2016) focussed on accounting and governmental practices deployed in the implementation of Fascist Reclamation Consortia. The main focus of these studies has been the way in which accounting practices contributed to the creation and management of a Fascist economy. There is no strong presence in the accounting literature of studies that have sought to analyse how accounting was used by individuals and institutions in implementing the increasingly oppressive control of the Fascist State. The study contributes to the existing Foucauldian literature by investigating the unravelling of the power relation between the Fascist government and the University within the reform of the Italian education system. It does so by documenting the shifting tactics employed by the government and their impact on the University and the territory of Ferrara when the University resisted the attempt to undermine its independence, which was essential to protecting access to higher education for working class youth. Resistance from the University meant that the government was forced to re-focus its initial strategies to subjugate the University by intervening in the accounting and funding system of the organisation while seeming to protect its status as a Free University. 
To pursue its aims, the study has used the extensive primary sources gathered from the historical archive of the University of Ferrara (AUF), with particular attention to financial statements, budgets, statutes, yearbooks of the University, correspondence with the central government and reports prepared by the Board of Directors and the Council of the University during the period 1922-1943. Other materials were obtained from the historical archive of the Municipality of Ferrara (AMF), most especially in the form of budgets and related commentaries of the Municipality, the main funder of the University. Documents drawn from the Ariostea Library in Ferrara (AL) were also used, most especially the Relazione intorno all'attuazione del Decreto Ministeriale 14 Febbraio 1860 (Report on the enactment of Ministerial Decree of $14^{\text {th }}$ February 1860 , henceforth Relazione), through which the University of Ferrara was set up as a Free University. Analysis of the University's financial statements and budgets has provided especially valuable insights to understand the effect of Fascist intervention in the University as the government's strategies changed in response to defiance by the University. The associated narrative reports, totalling almost 4,000 pages, were carefully examined to understand the dynamics of the evolving confrontations between the University and the Fascist government. An important source has been the speeches delivered by Gentile before the Italian Parliament, which are preserved in the historical archive of the Senate in Rome (AS). These have provided penetrating insights about the aims of Gentile's reforms and the ways in which they were implemented. 
The remainder of the paper is organised as follows. After reviewing the way in which Foucault conceptualised the relationship between power and resistance, intervention by the Italian Fascist State in universities is documented, most especially through an analysis of the comprehensive reform of the Italian educational system propounded by Gentile. The case of the University of Ferrara is then analysed, mainly through the primary sources, documenting how accounting was deployed by the Fascists in their attempt to curtail the independence of the University and how the latter sought to resist with the use of accounting information. A discussion of the main findings and conclusions is then presented.

\section{Power and Resistance}

As a medium of change, power has "a transformative capacity, the ability of an individual to influence and modify the action of other individuals in order to realize certain tactical goals" (Heller, 1996, p. 83, emphasis in original). The ultimate goal of having power is to "structure the possible field of action" (Foucault, 1982, p. 790) by prescribing a set of predetermined behaviours which are consistent with the goals of those exercising power. This relationship reaches its climax, a "state of domination", when one group "manages to block a field of relations of power, to render them impassive and invariable and to prevent all reversibility of movement" (Foucault, 1988, 
p. 3). Thus, the exercise of power depends on a complex interrelation between the actions of different subjects within a power network (Miller \& Rose, 1990; Neu \& Heincke, 2004). This means that domination is never achieved in a straightforward, uncomplicated way by silencing at the same time any other conflicting will through constant control and subsequent subjugation.

Supreme power is not the obvious result of a single, cohesive and rational will which ensures that the goals of the dominant elites are perpetually attained. Instead, Foucault believes that when power is exercised it will always be confronted by other forms of power which seek to achieve a different set of material and symbolic interests. The interaction between different forms of power will depend on the creation of discourses which enable the objectification of the goals of those exercising power and their articulation through language (Kosmala \& McKernan, 2011). The result is a "complex and unstable process whereby discourse can both be an instrument and an effect of power, but also hindrance, a stumbling-block, a point of resistance and a starting point for an opposing strategy" (Foucault, 1978, p. 101, emphasis added). Power as a 'struggle' means that its exercise will necessarily generate resistance (Foucault, 1978, p. 95). Resistance is not only complementary to power, it is the conditio sine qua non for a power relationship to exist; the exercise of power implies the opportunity for freedom. 
Power can only be exercised on free subjects, on individuals who can choose between different courses of action and react (Foucault, 1982).

There is a considerable body of research that has shown how accounting as a discursive practice in the enactment of power, with its specific and technical language, can be used to define which values and ideals are to be pursued. It has the ability to provide the moral underpinnings for power structures and to legitimise the exercise of power of some groups or organisations over others (Hopwood, 1992; Riccaboni et al., 2006). Accounting has the potential to create a legitimate language and meanings which help to make political questions look eminently technical (McKinlay \& Pezet, 2018; Farjaudon \& Morales, 2013), hence concealing the exercise of power and thereby empowering those who possess this technical knowledge. It has the potential to "rationalize and justify decisions that are largely a result of power and influence, in order to make these results acceptable and legitimate in the organization" (Pfeffer, 1981, p. 184). Accounting can therefore ease the process of resource allocation in favour of those in power in an unobtrusive way, providing legitimacy for political decision-making (Covaleski \& Dirsmith, 1988; Markus \& Pfeffer, 1983). As a result, accounting and its efficiency rhetoric can be a potent tool to make power strategies look objective, neutral and disinterested whilst the reality is that they are enacted to reproduce or reinforce unequal power relations (Baños, Domínguez \& Gutiérrez, 2016; Neu, 2006). 
Accounting practices provide the means to make individuals and organisations calculable and accountable for their performances and behaviours which can then be compared against a standard of conduct set by those in power. The result is an ability to exercise a detailed and individualised intervention on each and every subject with the aim to minimise deviations from the norm to overcome resistance (Miller, 2001; Miller \& O’Leary, 1987). This, concludes Foucault (1995), constitutes disciplinary power. Progressively from the $16^{\text {th }}$ century until the $18^{\text {th }}$ century power ceased to manifest itself in the form of spectacular and violent displays of the might of the sovereign and, instead, started to be exercised through hidden, less obvious practices which constituted disciplinary power (Foucault, 1982). By directing attention to the individual body as a target of manipulation and training (Burrell, 1988, p. 226), these practices of disciplinary power sought to make individuals and groups useful and docile. At the same time, 'bio-power' (Foucault, 2007, 2008) targeted individuals as part of a homogeneous social body and sought to master the whole population through knowledge of its broader phenomena (Foucault, 1995). Institutions such as schools, universities, mental asylums or clinics ensured that these forms of power seeped deep throughout society. 
The tool that is used to achieve power, such as accounting, can also be used to resist by being turned against those who employed it in the first place. Accounting knowledge can enable the mobilisation of effective resistance by "exposing the arbitrariness and selectivity of accounting procedures and the incompetence or partiality of accounting practitioners" (Ezzamel, 1994, p. 220), thereby showing the hidden purpose of apparently neutral accounts (McPhail, 1999). Research by Baños, Domínguez and Gutiérrez (2016) has focussed on a government plan in $18^{\text {th }}$ century Spain that was meant to improve tax collection and reduce excessive spending. This plan, which was grounded in techniques based on accounting, was successfully resisted by the Spanish bureaucracy when it contested the new governmental discourse on its own terms. Moreover, Andrew and Cahill (2017) showed how the Australian government's attempt to privatise two prisons in New South Wales in the name of improved efficiency was backed by the means of accounting. This discourse was resisted by union and community groups with the same tools to show how a focus on costs failed to capture the long-term effects of privatisation on local communities. Outside the sphere of government, practices of resistance to change that are promoted by means of accounting have also been documented in the context of factories (Knights \& Collinson, 1987; Ezzamel, Willmott \& Worthington, 2001; 2008). 
The presence of an "archipelago of different powers" (Foucault, quoted in McKinlay et al., 2010, p. 1019), the inevitability of resistance, the possibility of re-utilisation of discourses, including accounting, for opposing purposes means that even when the objectives of a programme of government are clearly set out by its proponents its actual outcome cannot be a priori known or controlled because of the complex interrelation between the exercise of power and the resistance that it confronts ${ }^{4}$. As a result, the presence of unexpected strong resistance or the rise of unintended outcomes may lead those involved in a power relationship to revise and re-focus their strategies to seek to achieve success in the power struggle. This was exemplified by the clash between the Fascist government and the University of Ferrara, which the government sought to bring under its exclusive control.

\section{The Fascist State and the Role of Universities}

The Fascists needed to 'build the new Italians' necessary to create a new national consciousness, a new way of life informed by Fascist values (Lyttleton, 1973, p. 381). This implied a search for uniformity and efforts to influence and control cultural and artistic expressions to shape the will of the people (Lyttleton, 1973; De Grand, 1994). In order to minimise opposition to their plans and gain the allegiance of people to the

\footnotetext{
${ }^{4}$ Foucault explains this by highlighting how power relations are both intentional and non-subjective (Foucault, 1978, p. 94; see also Foucault, 1980). Power is intentionally exercised to achieve certain objectives, but their achievement cannot be controlled by any particular individual as no one can control the entire power network.
} 
regime in the pursuit of the 'new man', action on new generations was particularly important. Mussolini and other Fascist leaders believed that youth played a fundamental role in the continuation of the regime. For this reason, the unchallenged control of schools and universities became an objective of the highest importance (Lyttleton, 1973, p. 402).

Gentile, consistent with the view of the Fascist 'right', saw in the education system a means to protect the existing social order which would have guaranteed the stability of the regime. The Fascists believed that progress would always be achieved by elites, in contrast to the 'masses' who are "matter, not spirit" (Mussolini, 1956a, p. 410); they do not have a clear purpose and always need a guide. Thus, the Nation has to be guided by an 'enlightened' elite, the formation of which was a function of the education system. The education system was also meant to ensure that the position of this elite would not be threatened by any unemployed who were highly educated and, thus, who could have been a dangerous source of criticism to the regime. This was a priority for Gentile who noted that the number of graduates from universities and non-vocational secondary schools was "enormously higher than was needed" (Gentile, 1924, p. 17). Therefore, the reform created clear paths after primary school with the introduction of new vocational schools which did not allow access to higher education. Moreover, a series of examinations for admission, eligibility, promotion and professional qualification were 
introduced with the aim of filtering and regulating the flow of students (Barbagli, 1982, p. 130). These were important means of social control: "early selection prevents raising the hopes of large numbers of people who might otherwise become the discontented leaders of a class challenging the sovereignty of the established elite" (Turner, quoted in Recchi, 2007, p. 401). At the same time, university fees were increased, thus transforming universities into places where a small, wealthy elite of people was formed to become the new ruling class. Gaining control of these institutions meant winning the battle of forming the next ruling class according to the will of the Fascist Party.

The educational reforms promoted by the Fascists, one of the first laws issued by Mussolini's new government ${ }^{5}$, reflected the priorities set by Giovanni Gentile when he became Minister of Education in 1922 and his idea of an "Ethical State" (Gentile, 1928; Mussolini \& Gentile, 1961). In marked contrast with 'individualist' liberalism and the minimal state, the State as an ethical entity had a life of its own and was there to protect the interests of the Nation, which was made up of past, present and future generations of citizens bound by a common language, values and religion (Gentile, 1928). To achieve this the State had to intervene in every aspect of the life of its citizens who, in turn, needed to leave aside their interests to pursue those of the Nation, if necessary to the point of self-sacrifice. This Ethical State could only be achieved, according to Gentile,

\footnotetext{
${ }^{5}$ This comprehensive reform was enacted through four different Royal Decrees: n. 1054 of $6^{\text {th }}$ May 1923; n. 1753 of $16^{\text {th }}$ July 1923 ; n. 2012 of $30^{\text {th }}$ September 1923 ; n. 2185 of $1^{\text {st }}$ October 1923.
} 
by making reform of the education system a priority of the Fascist government because it was clearly the "prerequisite of every other State function, as the alphabet is the baptism of every civilized man" (Gentile, 2004, p. 24). According to Gentile "the school system gathers in itself all the energy of life, it needs a clear rule more than any other form of life" (AS, Gentile, Senato del Regno, $3^{\text {rd }}$ June 1927, emphasis added). It is not surprising, therefore, that Mussolini proclaimed that Gentile's reforms were "the most Fascist of all the reforms passed by my government" (Mussolini, 1956b, p. 366).

Gentile's reforms applied to all educational institutions, most importantly Kingdom Universities and Free Universities, even though they differed in some fundamental characteristics, most importantly the way that they were funded. Although initially it never directly or openly opposed Free Universities, the Fascist government was keen to undermine their independence to ensure a total, unitary control of higher education consistent with the priorities of the Fascist State. Gentile clearly stated in an address to the Italian Parliament that Free Universities "too often have gone way farther than others for which the State provided ...; it is a fact that we have to be mindful of the advantages these institutes [Free Universities] have enjoyed vis-à-vis State [Kingdom] Universities" (AS, Gentile, Senato del Regno, $27^{\text {th }}$ November 1922) ${ }^{6}$.

\footnotetext{
${ }^{6}$ Gentile was referring to the ability of Free Universities to set the level of student fees and invest their resources without reference to the priorities of the State.
} 
To ensure the success of his reforms, Gentile also introduced a comprehensive set of social rules and practices to control academics, students and university administration. Although the independence of academics from political power was ostensibly formally protected, they were required, before taking office, to swear an oath of loyalty to the regime. The oath was made compulsory in 1923 but the formula was changed in 1927 and 1931 to make it explicit that professors had to declare their loyalty not only to the State but also to the Fascist Regime ${ }^{7}$. From 1927 the government could remove from office those professors who "through their behaviour within or outside the workplace, did not show the loyal discharge of their duties or were demonstrated not to be in line with the general political guidelines" (AS, Gentile, Senato del Regno, Documenti, Legislatura XXVII, $1^{\text {st }}$ session, $18^{\text {th }}$ May 1927).

In Kingdom Universities, which were the majority in Italy, the funds came from the State. This meant a closer control exercised by the State, but also the availability of ample resources to fund research and teaching. Kingdom Universities included the largest universities in the Italian territory ${ }^{8}$, which traditionally had been able to attract

\footnotetext{
${ }^{7}$ The oath imposed by Royal Decree n. 1227 of $28^{\text {th }}$ August 1931 reads: "I swear to be loyal to the King, to his Royal successors and to the Fascist Regime, to abide by the Statute and the other laws of the State, to attend to my teaching and academic duties for the purpose of forming decent, hard-working citizens devoted to the Motherland and the Fascist Regime. I swear I do not belong nor I will belong to any associations or parties whose activity is not consistent with the duties of my office".

${ }^{8}$ At the time when the Fascists came to power, the largest and more prestigious Kingdom Universities were those of Bologna, Cagliari, Genoa, Naples, Padua, Palermo, Pisa, Rome, Pavia, and Turin (Charnitzky, 1996).
} 
professors by their ability to provide higher salaries (Charnitzky, 1996; see also AUF, Series 16.1, 55, 1930). Their location in large cities and the presence of renowned professors in turn enabled them to attract a large number of students. In contrast, Free Universities had to provide for themselves to satisfy their financial needs and were allowed to use their resources as they decided. The main sources of income of Free Universities were student fees and contributions by the local municipalities and provinces where the universities operated. Some universities were also able to raise further resources from local charities and associations or private donors. The lower fees that Free Universities charged were an important means to attract students. This meant that students from the middle and working classes could have been able to access higher education, which was inconsistent with the elitist aims of Gentile's reform.

Gentile's reform was built on a Law passed a few months before the Fascists came to power (Law n. 1147 of $25^{\text {th }}$ July 1922) which raised the level of Free University student fees to that required by Kingdom Universities. At the University of Ferrara the Faculty of Law student fees increased in 1922 from 640 lire per student to 795 lire (a 24\% increase), those for Science went from 390 lire to 600 lire (+54\%) and the Faculty of Medicine saw an increase from 350 lire to 500 lire (+43\%) (AUF, Series 10.1, 25, 1923, 
p. 39$)^{9}$. The considerable increase in fees succeeded in making access to higher education more difficult for the poorer students, thus emphasising the elitist intentions of the Fascists. Ultimately, the drop in the number of students matriculating caused by the increase in fees generated a much higher burden to be borne by those universities which did not rely on State support, most especially the Free Universities. If Free Universities were unable to fund their activities, then by the Royal Decree they would lose their status as a Free University and come under the absolute control of the Fascist government, or face closure. This in turn had significant social consequences for working class youth, who could have turned to Free Universities to access higher education, by making it harder for them to achieve upward social mobility.

After Gentile's reform, both the Kingdom Universities and the Free Universities were given apparent administrative autonomy. However, this was to be conducted under State vigilance enacted through highly detailed measures. All universities were required to draw up a new Statute to implement Gentile's reform and demonstrate the financial viability of their new teaching offers. The Statute then had to be sent for approval to the

\footnotetext{
${ }^{9}$ Pharmacy and Obstetrics student fees rose from 370 lire to 490 lire $(+32 \%)$ and from 92 to 135 lire $(+47 \%)$ respectively. The new fees represented $17 \%$ of the average salary of a professor of Law, $13 \%$ of the salary of a professor of Science and 8\% of the salary of a professor of Medicine. Professors were paid on the basis of the number of modules they taught, with a different amount depending on the module being compulsory, elective, annual or biannual. Some of the professors in the Faculty of Medicine were expected to teach four to five modules.
} 
Higher Council of Education ${ }^{10}$ within the Ministry of Education, this testifying to the pervasiveness of the control exercised by the State. The Statute of the universities became a tool used by the Ministry of Education to modify the organisation of all universities and to influence the teaching offered. Control did not end with the approval of the Statute. The Ministry of Education and the Ministry of Finance had the possibility to order inspections of universities, thereby enabling an even stricter and never-ending scrutiny of the courses offered to ensure their consistency with Fascist aims but also how funds were used by these institutions. Thus, budgets and financial statements were to be sent to the Ministry of Education for approval at regular intervals by all universities, whether a Kingdom University or a Free University. These financial interventions required by Gentile's reforms were to provide the Fascists with the means to undermine and finally destroy the independence of the University of Ferrara.

\section{The University of Ferrara and the Threat to Independence}

At the time that Alberto V D'Este founded the University of Ferrara in 1391, with the approval of Pope Bonifacio IX, only three courses were offered: Arts, Theology and Law. The University, as in the medieval tradition, was subject to little or no influence from public powers. It depended mainly on fees paid by students who had the power to

\footnotetext{
${ }^{10}$ The Higher Council of Education, an advisory body to the Minister of Education, was set up originally in 1847 in the Kingdom of Sardinia. It was composed of academics and experts in educational matters. This was confirmed by Gentile's reform. However, it required that all of its members were to be appointed by the Minister himself (Ciampi \& Santangeli, 1994).
} 
hire their professors (Grendler, 2002). Maintaining a high degree of autonomy was still a priority of the University when the Casati Law was issued in 1859 , by which all the universities of the Kingdom of Sardinia, in which the city of Ferrara was located, became part of the structure of the State. The University ${ }^{11}$, however, was not prepared to come under the control of the State and hence fought for its independence.

To defend its position after the Casati Law, in a document called the Relazione the University emphasised the importance of its independence for the delivery of quality teaching and research. It noted how the decline of universities, which were born free in the Middle Ages, started when public powers sought to influence their activity by “appointing men [professors], always loyal to power, often known for their ignorance, or ready to bend their teaching to the needs of those in power" (AL, Relazione, p. 3). The need to escape any possible influence over professors and over the use of resources was seen as essential to ensure that the University could continue to "promote the dignity of science and attend to the needs of the community" (AL, Relazione, p. 4). As a result, the University appointed an ad hoc committee which demanded that the government return to the institution "what rightfully belonged to it, that is the power to organise its activity [...] and appoint professors as it saw fit, leaving the government

\footnotetext{
${ }^{11}$ In documenting the interrelationship between the organisation and the government, the word "University" is used to reflect the views of its ruling body, the University Council and, following Gentile's reforms, the Board of Directors.
} 
just its high vigilance over public order" (AL, Relazione, p. 2). This discursive argument was then reinforced by means of accounting information to make it more credible.

The Relazione (AL, Relazione, pp. 11-12) included a statement of forecasted revenues and expenses which demonstrated how the contributions of the Municipality of Ferrara and of the Province of Ferrara would allow the University to survive and prosper without relying upon State funding. Therefore, from the very inception of the University as a Free institution accounting was used as a tool to defend its independence and gain legitimacy (Moll \& Hoque, 2011; Peters, 2001). The combination of accounting and non-accounting arguments (Ezzamel, 1994) proved successful in allowing the University in 1860 to achieve the status of Free University, which meant that it could organise its activities and teaching offer without reference to the priorities of the State. The State would retain the power only to approve the Statute under which the University operated.

Even after the advent of Fascism, the status of being a Free University was perceived as essential by these institutions to guarantee their prestige and their ability to deliver the truly high-quality education which was pivotal in attracting new students. The Rector of the University of Ferrara in 1923 reminded the new Fascist Government that the 
University "enjoyed higher prestige than Kingdom Universities" (AUF, Series 10.1, 25, 1923, p. 33). This reputation enabled it to enrich the local economic and social fabric, with over $48 \%$ of its students coming from areas other than Ferrara (Yearbook, 19241925, pp. 123-129) ${ }^{12}$. It provided lawyers, and also doctors and nurses for the local hospital, chemists who would have supported the city's nascent chemical industry, and agronomists, who were important to a rural area such as that of Ferrara (Pepe, 2003). As a result, the University enjoyed strong connections with the municipalities in the Province of Ferrara and with local organisations such as the local hospital, the local Medical Association and the Chamber of Commerce.

As required by Gentile's reform, in 1923 the University had to update its Statute to ensure that its governance and teaching offer were consistent with the provisions of the new law. The reform made it clear that each University could have had four main faculties, namely Medicine, Law, Science and Humanities ${ }^{13}$, although it did not specify the modules which were to be offered. At the start of the Fascist period the University of Ferrara was made up of three faculties, Law, Medicine and Science, and two schools, Obstetrics and Pharmacy, the latter two which offered professional courses. According to the new Statute, a Senate and a University Council were entrusted with the duty to

\footnotetext{
${ }^{12}$ Students were not only attracted from nearby areas, but also from the far south of Italy and even from abroad, with students from Croatia, Montenegro and even Brazil.

${ }^{13}$ Courses could also have been offered by schools within a university. However, these did not lead to the awarding of a degree.
} 
administer teaching and research (AUF, Statute, 1924). From 1925 the University Council ${ }^{14}$ was replaced by a Board of Directors which had the same powers but the composition of which was changed markedly by Gentile's reforms.

The Board of Directors was effectively the ruling body of the University, whilst the Rector was ultimately responsible for the administration of the assets and resources of the organisation and the management of teaching and research activity (AUF, Series 10.1, 25, 1923, p. 32; AUF, Statute, 1924). The Board was responsible for preparing the budget and the financial statements of the University. In a similar manner to other universities in Italy, the governance of the organisation was significantly impacted when Board members appointed by the State could intervene in the management of the institution and report to the Ministry of Education ${ }^{15}$. However, in the case of the University, their presence was counter-balanced by that of representatives of the organisations which had traditionally supported the University through funding. These

\footnotetext{
${ }^{14}$ The University Council had included the Rector, six representatives of the Municipality of Ferrara, the President of the Province of Ferrara, one representative of the 'Cassa di Risparmio', the main bank in the territory, one representative of the local Chamber of Commerce, the President of the Provincial Department of Education, the Heads of the University's Faculties and Schools and three student representatives. The Board of Directors was composed of the incumbent Rector, the former Rector, the Mayor of Ferrara, four representatives of the Municipality of Ferrara, two representatives of the Province of Ferrara, two representatives of the small municipalities in the Province of Ferrara, the Heads of the University's Faculties and Schools, one student representative for each Faculty and School, one representative for any organisation which contributed at least 10,000 lire per year and one representative of the Ministry of Education. Following the introduction of a degree in 'Science of Corporations and Trade Unions', a representative of the Ministry of Corporations was added.

${ }^{15}$ At the University of Ferrara these were normally high bureaucrats or even members of Parliament. They would hold a degree and often be members of a profession, most especially lawyers. Some of them were even people entrusted with a high honour, such as the Order of the Crown of Italy.
} 
included not only the Municipality and the Province of Ferrara but also local banks and the Chamber of Commerce.

In the report attached to the new Statute of the University sent to the Ministry for approval, which also included the required financial plan to demonstrate the financial viability of the amended teaching offer, the University clearly stated how the review of the existing Statute had been informed by "those principles of freedom and independence to which the University has always been faithful" (AUF, Series 10.1, 25, 1924, p. 134). It sought to make clear that it was committed to preserving its autonomy and independence from central government. However, to the great disappointment and consternation of the University, upon receiving the University's new Statute and the related documents the Ministry on $21^{\text {st }}$ August 1924, in a highly provocative and unprecedented action, reacted by closing the University's Faculty of Medicine (AUF, Series $10.1,25,1924$, p. 57). The Ministry explained that the Faculty did not meet the quality requirements imposed by the law by offering only three of the five years required for a degree in medicine. On this Gentile was not prepared to compromise ${ }^{16}$ (AUF, Letter of the Minister of Education to the Rector, $23^{\text {rd }}$ August 1924; AS, Gentile, Senato del Regno, $3^{\text {rd }}$ June 1927).

\footnotetext{
${ }^{16}$ At the same time, a proposal to reform the degree in Science was first rejected and later approved only after the University adopted the suggestions coming from the Ministry of Education and had secured an extra grant of 50,000 lire from a local foundation (AUF, Series 16.1, 55, 1925, pp. 28-29).
} 
When the University was set up as a Free University it did not have enough financial resources and professors to offer a degree programme of five years (AL, Relazione, $\mathrm{p}$. 8). Nevertheless, it decided to offer a three-year programme which would have still allowed a student to have an advanced training in medicine and hence find a qualified job in the local area. If students wanted to complete their studies they would go to another University, usually Bologna nearby. The interpretation provided by the Ministry of art. 4 of the reform meant that 'incomplete faculties' did not fulfil the need to provide students with a sound and thorough education which would have resulted in an academic title to certify their ability to undertake a highly qualified job (Charnitzky, 1996). Consequently, to justify its highly provocative actions the Ministry said that it was not prepared to allow the University to have an incomplete faculty (AUF, Series $10.1,25,1924)$.

The closure of the Faculty, which had been in existence since 1391 (AUF, Series 16.1, 55,1926 , p. 59), not only would have damaged the prestige of the University, but would have also had considerable social and economic consequences for Ferrara. Local students would have had to attend universities in another city, hence adding travel and lodging expenses to the already high fees. This also deprived the local area and its economy of highly qualified individuals. Irrespective of the justifications given by the 
government, the closure of the iconic Faculty of Medicine, upon which the national and international reputation of the University was largely founded, would have shown to all universities the determination of the Fascist government to implement the dramatic changes that they were seeking to introduce. It was a means for the Fascists to proclaim that they were not intimidated by any possible opposition, even from an elite university, and that there was nothing beyond their control in the implementation of their vision of the State, to which harnessing the education system was pivotal.

Given the history of the Faculty and its importance more broadly for the reputation of the University, far from being compliant, the University was determined to fight for the Faculty and most especially its independence and traditions. One of the members of the Board of Directors even resigned in open opposition to the decision of the Ministry (AUF, Series 16.1, 55, 1924, p. 9). Another member of the Board was not afraid to protest that "we should keep the Faculty of Medicine at all costs, for the decorum of our University" (AUF, Series 16.1, 55, 1925, p. 30). This defiant stance was backed not only by the students of the University but also by the Municipality of Ferrara and the Local Medical Association, which would have witnessed a reduction in its membership. Bravely, the Board of Directors and the Rector were determined to reintroduce the Faculty of Medicine despite ministerial ostracism. The University was not prepared to accept tamely the decision of the totalitarian government but, instead, was ready to fight 
"all the damage suffered by the University", referring to it as "this despicable mutilation" (AUF, Series 16.1, 55, 1925, p. 58). The strong stance of the Board was also surprisingly backed by a prominent Fascist Party official who was born in Ferrara, Italo Balbo. It also was reiterated by the Rector in his opening address during the celebrations for the inauguration of the 1924-1925 Academic Year when he spoke again of the "serious mutilation of the structure of the University" (Yearbook, 1925-1925, p. 18).

To take advantage of its traditional independence to resist and protect its integrity, the University mobilised support from local bodies (Ezzamel, 1994), both private and public, which would have been damaged by the 'mutilation' suffered by the University. It also became obvious very quickly that the University's efforts to reverse the government's decision about the Faculty of Medicine would have to rely upon discourses consistent with those used by the government to justify its decision. Most especially, this would be based on financial considerations provided in accounting reports.

\section{Accounting for Control and Resistance}

\section{The Struggle Begins: the Re-Appropriation of Accounting Rhetoric}

Rather than engaging in a highly subjective, and therefore far less certain, discussion on the quality of teaching and learning to justify the closure of the Faculty of Medicine, the 
power relation created by the Ministry of Education was sustained by a discourse based on financial sustainability. This obviously and explicitly depended for its legitimacy upon accounting information. Thus, to defend its intractable position the Ministry sought to divert any discussion to the more neutral and seemingly factual field of administrative and financial capability (Covaleski \& Dirsmith, 1988). After repeated attempts to get the government to reverse its decision to close the Faculty of Medicine, following an inspection on $6^{\text {th }}$ September 1924 , which in a very threatening manner questioned the University's overall financial stability, the University was asked to submit a new financial plan by October 1925 (AUF, Series 16.1, 55, 1925, p. 28). To reinforce the deceptive credibility of its request the Ministry also required the University to provide budgets for the faculties of Law and Science and the School of Obstetrics. The recourse to accounting reports helped to make the government's action look eminently technical and placing it beyond political debate (McKinlay \& Pezet, 2018; Neu, 2006; Rose \& Miller, 1992). It also gave the impression that the alleged failings of the University involved far more than just the Faculty of Medicine. The Minister emphasised how the closure of the Faculty of Medicine had been "painful but necessary" by the "scant" resources available (AUF, Letter of the Minister of Education to the Rector, $23^{\text {rd }}$ August 1924). Although the strong financial basis of the discourse relied upon by the government to justify its decision to close the Faculty of Medicine was meant to be difficult to rebut, a discourse that "transmits and produces power" also 
"undermines and exposes it, renders it fragile and makes it possible to thwart it" (Foucault, 1978, p. 101).

The attempt by the Ministry to shift the focus of the objections of the University to an accounting discourse was successful but it also provided the University with the means to turn the discourse against the government itself. The minutes of the Board of Directors of the University show that its entire discussion about the Faculty of Medicine became focussed on accounting matters. It was the only discourse that they now recognised as possible with which to engage the government, rather than questioning the decision of the government on other grounds such as the importance of the Faculty for the prestige of the University and for the wellbeing of the local citizens. The response by the University clearly indicates that it realised that if it was to overturn the government's decision it would have to engage with the government using the financial discourse that the government had created. It would have to do this in a manner which would re-appropriate this discourse (Gordon, 1980; Andrew \& Cahill, 2017) by demonstrating how the financial and academic viability that the Ministry said was not possible would be achieved by the Faculty of Medicine.

In a similar manner to when the University was able to gain the status of Free University, it sought to mobilise accounting to demonstrate the arbitrariness of the 
government's decision and of the related accounting calculations (Ezzamel, 1994). As a result, an accounting discourse was used to serve strategies seeking to pursue opposite goals to those of the government and thereby be the means of resistance (Foucault, 1978). All of the Board members recognised the dissonance of the financial basis of the discourse which the University was forced to adopt in the context of what was essentially a matter of scholarship. This led them to insist on the need to prepare a financial plan which was "carefully studied in all of its parts" with the participation of an "external member with sound technical [accounting] knowledge" (AUF, Series 16.1, 55, 1925, pp. 32-33). The Board was in effect seeking to use against the government the discourse that it had created by placing the government in a position where to reject a convincing financial case by the University would be to expose the real political intent of the Fascist government's actions.

The contributions of accounting experts were to be essential in reinforcing the credibility of the University's plan and in turning the accounting and efficiency discourse against its proponents (Rose \& Miller, 1992). Hence, the Rector in 1925 formed an internal commission of five members, of which one was a professor with accounting expertise, to collect data for the Ministry. The commission sought to demonstrate that effective financial plans were in place for the reintroduction of the Faculty of Medicine under a set of conditions which met all previous criticisms, most 
especially the financial stability of the Faculty. Upon receiving the commission's report, the Higher Council of Education took a long time to analyse the document presented by the University, possibly in an attempt to slow down and bureaucratize the process. Unable to reject the strong financial case provided by the University without questioning its own methods, another request from the Ministry to the University to submit a new budget resulted, along with the request to gather more resources from the main funders of the University, the municipalities located in the Province of Ferrara. Soon after, on $29^{\text {th }}$ March 1926, there was an unexpected announcement by the Ministry which, through the Royal Decree $n^{\circ} 119$ of February $4^{\text {th }}, 1926$, allowed the possibility for the University to re-open the Faculty of Medicine after the submission of further financial details. However, again responses from the University were limited by the financial discourse rather than the quality of the renewed programme now proposed.

The University highlighted how it could count on a remarkable amount of reserves and that increased contributions from funders were not needed (AUF, Series 16.1, 55, 1926, p. 6). In its report the University demonstrated that quinquennial agreements with local governments were in place. It also provided a detailed description of the assets to be used for teaching purposes, including historical information about the main laboratories and other properties. This had been attached to the financial plan. Despite the strong financial case provided by the University, the Higher Council of Education decided one 
year later to deny finally every possibility to reintroduce the Faculty of Medicine. This decision again was justified exclusively on financial grounds. These emphasised mainly the alleged dubious capacity of the University to secure contributions from local funders in the long run and the absence of adequate assets to deliver the proposed teaching:

it has not been demonstrated that clinics and medical institutes will be provided with adequate scientific and teaching equipment, nor that financial resources needed exist or can exist ... Moreover, since it is not possible to offer adequate salaries to teaching assistants, it will not be imaginable to expect of them thorough knowledge and ongoing commitment (AUF, Series $16.1,55,1927$, p. 18).

To reinforce its claim and to create an understanding that the problems of the University extended well beyond the Faculty of Medicine, in its reply the Ministry now also questioned the financial stability of the Faculty of Science, whose relevant financial plans had been duly approved in the past (AUF, Series 16.1, 55, 1927, pp. 21-22). This discursive shift was an indication of the difficulty faced by the Ministry in overcoming the resistance of the University. By continually shifting the focus of the discussion from an explicit political context to one around accounting matters the State sought to disguise its attempt to subdue the University and portray itself as simply providing a rational response to technical problems (Covaleski \& Dirsmith, 1988, p. 6). This penetrating interference made the Board of Directors exclaim that ministerial intervention was not in line with "the spirit of autonomy, joint freedom and gravity promoted by Gentile's reform” (AUF, Series 16.1, 55, 1927, p. 56). 
Although the State had succeeded in demonstrating that it was prepared to overcome strenuous resistance to implement its vision of the new Fascist education system, the power relation was far from having been turned into a relation of domination (Foucault, 1988) after the University had shown that it was prepared to resist the will of the government and to counter the strategies it deployed. Accounting information had been used by the government to show that its decision to close the Faculty of Medicine was inevitable and entirely due to financial considerations. Nevertheless, the ability of the University to re-appropriate accounting and its rhetoric and to demonstrate that with the financial support of local institutions the Faculty could have provided an ongoing, high quality medical programme exposed the political purpose of the decision of the government. The Ministry may have succeeded in forcing the closure of the Faculty of Medicine but failed to subdue completely the University which retained for the time being its independence. This helped the government to realise that a different strategy, although still embedded in an accounting discourse, had to be deployed, one which would weaken the links the University had with its local supporters, the financial support of whom had been given particular prominence in the University's responses. 


\section{Increased Financial Pressure}

After an initial increase in the University's total income in 1923-1924 due to the rise in student fees, it started to fall in 1924-1925 as student numbers declined. As shown in Table 1, after 1923 there was a sharp decrease in the number of students in response to the increase in fees imposed by the reform, falling in 1927 to a third of the number of students enrolled in 1923 (AUF, Series 10.1, 25, 1923, p. 8) ${ }^{17}$. This clearly confirmed that the reform was succeeding in curtailing access to higher education, most especially for working class youth who would not have had the means to sustain the higher fees now implemented. The Communist Party sought to channel the discontent of the students of the University into open protests. However, the prompt intervention by State authorities meant they were soon silenced (AUF, Letter of the Minister of Education to the Rector, 29 $9^{\text {th }}$ March 1926).

The major impact of Gentile's reforms on the funding structure of the University was evident in its financial statements, where a dramatic decrease in total fees collected can be noted, from 161,835 lire in 1923-24 to 103,305 lire in 1927-28, a fall of $37 \%$. At the same time, operating expenses increased as Gentile's reform set faculty and staff wages at the same level for every university, consistent with the base salary received by those

\footnotetext{
17 The increase in fees was such that the average fees per student increased from $5 \%$ to $13 \%$ of the average salary of a professor, although the latter had been increased as well. It should be noted that the difference between old and new fees for current students had to be paid to the State Treasury, not to the Free University (AUF, Series 10.1, 25, 1923, p. 36).
} 
employed by Kingdom universities. As a result, between the academic years 1923-1924 and 1927-1928, personnel expenses for the University almost doubled ${ }^{18}$ (AUF, Series 10.1, 25, 1923, p. 87; AUF, Series 16.1, 55, 1929, p. 31).

\section{Insert Table 1 here}

The very considerable drop in income from student fees and the parallel increase in expenditure caused unprecedented pressure on the financial stability of the University. Thus, the University sought to protect its independence from the State by seeking additional financial support from its 'network of resistance' (Foucault, 1978; McPhail, 1999) made up of local public organisations and banks (AUF, Series 10.1, 25, 1924, p. 54). However, this produced an unsustainable increase in financial contributions from local funders, which nearly tripled in the period 1923-1925, increasing from 127,272 lire to 342,096 lire. The financial effort now expected of local funders signified the beginning of a financial crisis for the University which was mirrored by the emerging trend in the amounts owed by funders and the University's year-end financial position, as shown in Table 2.

\footnotetext{
18 The reforms also caused the University's contribution towards employees' insurance and pension to increase from $6 \%$ to $8 \%$ of the by then higher salary of the employee (AUF, Series 16.1, 55, 1925, p. 46).
} 


\section{Insert Table 2 here}

Table $2^{19}$ shows the effects on both local funders, the financial well-being of some which was strongly linked to that of the University (AMF, Series 21, 7.5, 1929), and the University from changes imposed on the latter's funding structure. Thus, Table 2 shows how the increasing magnitude of the requests to the funders from the University resulted in payments being late or not made at all. The analysis of the amounts owed by local funders (column 3), which represents the amount of cash the funders promised to contribute according to the budget less the sum actually paid over the accounting period, and the fourth column, the running total for the debts of the funders, clearly show how the financial burden that the funders had to carry soon became unbearable. This situation reached its nadir in the academic year 1926-1927 when, due to high expenses and uncertain revenue, the University sustained its first loss during the Fascist era, amounting to 23,703 lire. The University sought to carry out its work as usual through self-sacrifice without compromising its independence (AUF, Series 16.1, 55, 1926, pp. 25-26). This forced the Board of Directors to request the help of the employees, including requiring professors to teach extra hours without payment.

\footnotetext{
${ }^{19}$ Most of the contributions came from the Municipality of Ferrara, the grant of which was set at 110,000 lire in 1924. The Province of Ferrara contributed 70,000 whereas the other 20 small municipalities in the area contributed amounts ranging from 100 lire to 7,000 lire. These amounts were reviewed many times after requests from the University. Other sources of funding included three local banks and the Chamber of Commerce of Ferrara.
} 
The increasing, unmet, financial pressures on local funders meant that they were no longer able to sustain the University. This provided the government with a new strategy to overcome the resistance of the University without confronting it directly (Foucault, 1978; Heller 1996). The University now had to rely on the State for its financial needs if it were to survive.

\section{Accounting for Domination}

\section{Breaking the Local Network}

Control of the University was exerted not only at a distance from Rome but also the Fascist government was directly involved in making its power visible (Neu, 2000), most notably with the visit to the University in late 1927 of a commission headed by Giovanni Gentile. The presence of the former Minister of Education on the commission was emphatic confirmation of the importance of the matter and the government's determination to assess the University's diligence in implementing the reforms. During the visit the commission analysed the University's financial plans and the financial situation of the existing faculties, including auditing their expenditure. This seemingly thorough review of the University's finances gave Gentile the opportunity to impose new investments, which substantially increased financial pressure, in the name of improving the quality of teaching and overall efficiency (Hopwood, 1990; Neu, 2006). He concluded that laboratories and scientific instruments in the Faculty of Science were 
obsolete. Therefore, they required an investment of 250,000 lire every year for ten years to maintain a high standard of quality for the Faculty. This inspection was a clear sign of how financial imperatives were again used to achieve wider political aims (Hopwood, 1992) and to provide justification for a new strategy aimed at making the struggle for independence impossible for the University by placing it under further intolerable financial strain which would be enough to ensure its surrender.

The ultimate intent of the government was confirmed when it would have been clear to the commission that the extra investments demanded were not possible in the University's then current financial situation. The University sought to respond by mobilising again its local network of funders. Ferrara's 'Podestà', Renzo Ravenna ${ }^{20}$, was prepared to counter this further threat to the University's independence when he proclaimed that the Municipality would defend "strenuously, renewing its means and functions, our glorious University" (AMF, Series 21, 7.4, 1928, p. 21). He also sought to secure more funding from the region of Ferrara by asking local funders to increase their contribution as well as seeking support from smaller rural municipalities which had never contributed to the University's finances ${ }^{21}$. Unsurprisingly, gathering the required funds from local funders who were already behind in their contributions (see

\footnotetext{
20 The 'Podestà' was a monocratic organ of the municipality, appointed directly by the Government as a substitute for the mayor and the city council after Fascist local government reform. The contribution from the Municipality of Ferrara was increased by 45\% between 1927 and 1928 (AMF, Series 21, 7.4, 1928).

${ }^{21}$ This resulted in an increase in contribution from local funders from 352,000 lire to 603,311 lire (see Table 2 and Table 3 ).
} 
Table 2), and most of whom were small and could not count on many resources, proved to be unsuccessful. As a result, the year 1928 marked the first direct intervention of the government in the financial affairs of the University when an annual contribution of 170,000 lire was awarded by the Ministry of Corporations for a new degree in the Faculty of Law called 'Science of Corporations and Trade Unions'.

The new degree, which was proposed as a means to secure extra funding by widening the teaching offer of the University with the introduction of a programme which obviously recognised Fascist priorities, was of great interest to the government. It promised to provide a means to educate the future ruling class according to corporatist priorities and values which should now inform the Fascist economy (Cinquini, 2005). The only justification for the new degree provided by the Board of Directors confirmed that this deviation from the traditional teaching offer was clearly based on financial grounds. The Board noted that "this change will certainly be welcomed by the Ministry of Corporations, and the financial contribution which would certainly be granted for setting up this new programme would improve the financial situation of the University" (AUF, Series 16.1, 55, 1928, p. 13). The initial attempt to build the new degree programme mostly on the modules (and contents) offered within the existing degree in Law (Cazzetta, 2004) further testified that the reason for its creation was essentially 
financial $^{22}$. The enthusiastic approval of the new programme by the Ministry of Education and the Higher Council of Education, which made the University the first in the country to offer this programme (AMF, Series 21, 7.5, 1929), meant that the government's plan to intervene in the activity of the University and overcome its resistance by inducing a state of financial stress was starting to show results.

Accounting practices were instrumental in ensuring that the new programme was successfully implemented by the University and that the funds granted by the government would be spent only for the purposes of the new degree. The University was required to prepare, at the end of each academic year, a report detailing the progress of the degree, its teaching programme, the number of students enrolled and the fees that they had paid, in order to confirm and set the level of the government's contribution for the forthcoming year (AUF, Series 16.1, 55, 1928, p. 79). Moreover, further information, including module materials and the names of those teaching in the programme was requested through simple letters (AUF, Letter of the Minister of Corporations to the Rector, 22 ${ }^{\text {nd }}$ December 1927; AUF, Letter of the Minister of Corporations to the Rector, $4^{\text {th }}$ October 1929; AUF, Letter of the Minister of Education to the Rector, 26 ${ }^{\text {th }}$ March 1929). Therefore, the Fascist government succeeded in moulding the reporting system of the University for its own purposes.

\footnotetext{
${ }^{22}$ Of the 20 exams a student had to sit to graduate in the new degree, only four were not part of the traditional degree in 'Law' and were specific to the new degree.
} 
The financial and other information required by the government associated with the new degree restricted the possibility of the University using government funding or organising the degree and other existing programmes as preferred by the University. New accounting information that was now required would expose any deviations from the expectations of the government in Rome which would have meant the withdrawal of financial support. This would also have made it impossible for the University to seek to re-appropriate the accounting discourse to support a strategy of resistance (Foucault, 1978; Gordon, 1980). The accounts clearly showed that the activities of the University were not sustainable in the long term unless the extra funding from the State was maintained. The production by the University of dedicated financial reports for the government represented a legitimising practice (Riccaboni et al., 2006) that provided justification for the first direct, pervasive State intervention in the affairs of a traditionally independent institution.

In response to the difficulty of taming the University, the Ministry had been forced to change its strategy (Foucault, 1978) by promoting a new, more penetrating use of accounting information that gave precise visibility to the teaching programmes and outcomes, ensuring their consistency with Fascist priorities. Very importantly, the additional information now required about the sustainability of the new degree provided 
the means to legitimise intervention by the government in the teaching offer by making the advantages of government funding obvious to the struggling University and to its supporters. Government intervention was now crucial to the survival of the University of Ferrara. The dramatic, historic changes which the government forced upon the University, most specifically the brutal closure of its most important and internationally renowned faculty, the Faculty of Medicine, and the change in the fee structure, made the University realise that only by surrendering its independence would it be able to continue to survive.

So obvious had become the benefits of government funding for the University as shown by its accounts that, for the first time, one of the Directors noted how the solution to the financial struggle "might have been requesting to become a Kingdom university" (AUF, Series $16.1,55,1931$, p. 59, emphasis added). At that time, almost all of the Free Universities in Italy which were experiencing the same financial problems as the University of Ferrara were considering the advantages of becoming a Kingdom University (AUF, Series 16.1, 55, 1929, p. 27). This showed that the government's aggressive attacks on the independence of the University of Ferrara had the result desired: the indirect intimidation of other Free Universities. Thus, it appeared that the Free Universities of their own volition were seeking to become Kingdom Universities, that they had not been forced by the government to do so. The government therefore 
sought to demonstrate that not only did it not oppose traditionally independent institutions such as universities, but that it was prepared to support them in times of great difficulty. The government had been successful in structuring the possible field of action of the University without resorting to apparent coercion (Foucault, 1982, p. 790; Foucault, 1988). By means of substantial direct government funding and related accounting practices, which closely monitored the University's adherence to Fascist beliefs and controls, the government succeeded in instilling new values and priorities which had never been central to the life of the University in the past. The final and decisive tactic employed by the government to subdue the University was breaking the ties it enjoyed with local funders by increasing the already unsustainable burden that they were carrying. This was to isolate the University by silencing the "plurality of resistances" (Foucault, 1978, p. 96) emanating from the area of Ferrara, leaving the organisation exposed to the intervention of the government.

The financial statements of the University clearly highlighted how government funding, together with increased support by local funders, allowed it to achieve an overall profit for three consecutive years after the payments by the State began in 1928. Table 3 clearly shows that the profit achieved by the University almost mirrored the contribution granted by the Ministry of Corporations. Overall surplus amounted to 174,045 lire in $1928-1929,145,971$ lire in $1929-1930$ and 108,738 lire in 1930-1931, 
whilst government funding amounted to $170,000,120,000$ and 100,000 lire respectively. The falling surpluses over these years recognised the refusal of the Ministry of Education to permit the University to hire new academics and instead rely upon sessional teachers ${ }^{23}$, thereby allowing the government to reduce its funding (AUF, Letter of the Ministry of Corporations to the Rector, $18^{\text {th }}$ July 1929).

\section{Insert Table 3 here}

Financial difficulties were soon to re-surface when in 1931 the Board of Directors highlighted how difficult it was for local funders to maintain their payments (AUF, Series $16.1,55,1931$, p. 8). The enduring effects of the great depression spreading worldwide in 1929 added to the problems created by the revaluation of the lira undertaken by the government in 1927, most especially an increase in unemployment and a decrease in real wages (De Grand, 1994). The effects on Ferrara's territory became very obvious with the worsening financial situation of local municipalities. At the same time, one of the banks which had traditionally supported the University went bankrupt while the local association of retailers became unable to continue to provide support (AUF, Series 16.1, 55, 1930, pp. 4-7). Funders may have been still willing to contribute to the activity of their University but were often unable to keep their

\footnotetext{
${ }^{23}$ Not only was the advertising of new academic positions to be approved by the Ministry, its powers to intervene were greatly increased by Law n. 1.001 of $9^{\text {th }}$ June 1927.
} 
promises and debts kept on accumulating year after year, thereby generating obvious cash flow problems for the University. The situation in 1930-1931 is emblematic. Although the resources provided by the Ministry and local funders allowed the University to achieve a profit, unpaid debts for the year peaked at 237,109 lire whilst the running total exploded to 334,689 lire, three times the amount of profit for the year. Adding further disruption to the activity of the University was the decision by the government to increase the salary of professors teaching in Kingdom Universities. This made it harder for Free Universities, most especially for those in financial difficulties, to retain their staff (AUF, Series 16.1, 55, 1930, p. 56; 1932, p. 26). Once again the government sought to make it very difficult for these institutions to exercise what remained of their freedom and resist the power of the State (Foucault, 1982).

In a surprising and financially unwise last attempt to demonstrate its commitment to students and to the quality of teaching, notwithstanding the looming financial crisis, the University decided to take out a bank loan to rebuild the laboratories for its Faculty of Science as required by Gentile (AUF, Series $16.1,55,1933$, p. 9). The Rector proudly proclaimed how the University was prepared to play its part in the "spectacular competition ... with Kingdom universities ... with the sole means allowed by its modest finances" (AUF, Series 16.1, 55, 1933, p. 64). However, the financial crisis became more obvious in the period from 1931-1932 to 1935-1936 with, as seen in Table 4, a 
series of losses and just one year of profit. To put even greater financial pressure on the University, the Ministry of Corporations' annual contributions from 1931-1932 decreased to 60,000 Lire. At the same time, the financial statements were carefully inspected by University auditors who recommended writing off an amount of 106,473 lire which was deemed to be irrecoverable (AUF, Series 16.1, 55, 1932, p. 8).

The financial situation quickly deteriorated after 1931 and debilitating losses were incurred for the next five years. Unsurprisingly, the first loss in 1931-1932 was 106,617 lire, almost the same amount of bad debts written off. Municipal funding, following the bad debts write off and recognising the impossibility of keeping contributions on the level desired by the University, was reduced again from 514,931 lire to 439,931 lire in just one year. The financial crisis in this period reached its nadir in 1935-1936 when a loss of 149,180 lire was incurred, after another bad debts write off suggested by the auditors amounting to 108,102 lire. It was therefore clear how the power relationship between the University and the government was moving towards a relationship of domination (Foucault, 1988). The State had been successful by means of its revised tactics to counter the resistance coming from the University.

\section{Insert Table 4 here}


With the University's very existence now in question, the only way out of this situation was for the University to surrender its independence and formally ask the government to allow it to become a State-subsidised Kingdom University. When in 1934 the University of Ferrara considered requesting the government that it be allowed to become a Kingdom University, the Board made it clear that this decision was grounded almost exclusively on financial considerations. The Board of Directors' stressed that the increased needs of scientific offices, laboratories, libraries and maintenance are a financial burden which cannot be borne by the income of the University. The President thinks that it is essential that the State looks favourably to our University and that a financial plan for an honoured proposal to become a Kingdom University needs to be drawn up (AUF, Series $16.1,56,1934$, p. 12).

Following another reform in November 1935, which sought to reduce the teaching offer of all Italian universities, consistent with Fascist priorities, the University responded by formally requesting to become a Kingdom University (AUF, Series 16.1, 56, 1936, p. 8). It could no longer fight for its independence and the preservation of its unique character and features as it did in the past. The power struggle was therefore over; the government had succeeded in overcoming the resistance of the University by making the struggle financially impossible (Foucault, 1982).

\section{Surrender}

After its request to become a Kingdom University was submitted, the financial and other reports sent by the University to Rome became increasingly dense with Fascist 
rhetoric to highlight the commitment and contribution of the University to the regime. Examples include the Board emphasising how the University "feels and believes in the hope of the revolutionary times we live in and, notwithstanding the limits of its means, endures every sacrifice needed to follow the path which leads to the fulfilling of its new destiny" (AUF, Series 16.1, 56, 1935, p. 19). It praised also military intervention in east Africa as a means to allow Italy "to meet its sacred destiny" (AUF, Series 16.1, 56, 1936, p. 16). Further, the obligations and changing academic culture that followed greater State intervention meant that the University was more willing to take part in initiatives and celebrations organised by the government. The University started hosting Fascist events, which included evening courses of Fascist political culture or celebrations for military victories. In 1941 it awarded a degree honoris causa to the Nazi Minister of the Interior (AUF, Series 16.1, 56, 1941, p. 43). The teaching offer was also impacted when a new course, 'Biology of Human Races', was introduced following the issuing of racial laws in 1938 (AUF, Series 16.1, 56, 1939, p. 4). This confirmed the now unchallenged priority to be given by the University to the Fascist mission. Even the most reliable ally of the University, the Municipality of Ferrara, was prepared to recognise the benefits of Fascist intervention when the Podestà noted how it inaugurated "a period of gradually increasing floridity" for the organisation (AMF, Series 21, 10.2, 1943). 
The effects of the increasing dependence on the State were not limited to the teaching activity of the University. It now became a means to monitor the work and actions of professors and students and to secure the widespread diffusion of Fascist social policies. This was especially obvious after the University was required to give preference to members of the Fascist Party when employing staff (AUF, Letter of the Minister of Education to the Rector, $15^{\text {th }}$ April 1941; AUF, Letter of the Minister of Education to the Rector, $26^{\text {th }}$ June 1941). The University was now also expected to undertake a key role in the implementation of racial laws. Thus, in 1941 four Jewish professors were sacked "in a deafening silence" (Cazzetta, 2004, p. 209). On many occasions the Ministry requested the University to provide evidence of individual staff members or students belonging to the 'Arian race' (AUF, Letter of the Minister of Education to the Rector, $19^{\text {th }}$ July 1940; AUF, Letter of the Rector to the Municipality of Turin, $10^{\text {th }}$ December 1941; AUF, Letter of the Minister of Education to the Rector, $19^{\text {th }}$ July 1941). The University's now unquestioned allegiance to these priorities showed that it was prepared, in order to secure its survival, to become an implement of the Fascist State in the construction of the 'new Fascist man'.

After the University showed its willingness to become a fully functional body within the Fascist State, Benito Mussolini himself at an informal meeting in 1936 with the University Rector in Rome rewarded the institution by allowing it to reintroduce its 
Faculty of Medicine. This was despite the medical degree it offered being still incomplete, the very reason for the original campaign by the government against the University (AUF, Series 16.1, 56, 1936). This further betrayed the political motives of the government in previously closing the Faculty. Although in the past the Faculty was considered a highly 'inefficient' investment, now that the University had been made a more 'docile' institution the Ministry of Education was prepared to grant a sum of 350,000 lire for the reintroduction of the Faculty of Medicine (AUF, Series 16.1, 56, 1937, p. 6). This was increased to 400,000 lire from 1938. Once again, to emphasise the subservience of the University to the government's controlling needs (Sargiacomo et $a l ., 2016)$ the institution was required to account for the use of these funds in a new dedicated report to verify that these amounts had been used for the specific, approved purposes. As a result, a separate income statement was prepared for the Faculty of Medicine, this enabling a more penetrating control on how funding coming from the centre had been used. The income statement specifically for the Faculty of Medicine, as openly stated by the Ministry Inspector Dr Vallerini who inspected the University to oversee the creation of the Faculty, was also an attempt to highlight the benefits and achievements allowed by government contributions whilst other faculties were still in a state of financial crisis (AUF, Series 16.1, 56, 1937, p. 3) ${ }^{24}$. Accounting practices were

\footnotetext{
${ }^{24}$ Following a request of the University which was seeking to use profits generated by the Faculty of Medicine to cover losses incurred by other faculties, the Ministry openly forbade to do so as "ministerial contribution to the Faculty cannot be misappropriated in any way" (AUF, Letter of the Ministry of Education to the Rector, $3^{\text {rd }}$ September 1937).
} 
therefore again to provide legitimacy to the pervasive intervention of the State in the University (Riccaboni et al., 2006; Moll and Hoque, 2011). This would ensure that the benefits were so obvious that no use of counter-accounts to demonstrate the selfsufficiency of the University could have been possible. The international sanctions which followed Italy's conquest of Ethiopia in 1936 and the implementation of autarchic measures in preparation for the looming world conflict (Morgan, 1995) caused a further worsening of the economic situation and made it even harder for local funders to maintain their payments to the University. As a result, after the University requested to become a Kingdom University, government contributions soon became an even larger share of the total income of the University, as shown in Table 5.

\section{Insert Table 5 here}

The strategy of the government based upon a combination of funding policies and related accounting reports had been extremely effective and ensured that no action contrary to the influence of the State would have been feasible for the University (McPhail, 1999). Moreover, the Fascist government managed to shape the relationship of power to its advantage even without bearing the full weight of the University's funding as it did with Kingdom Universities. Whilst still de facto under overwhelming 
State influence since 1936, the University became officially a Kingdom University only in 1942, when the Regime was soon to fall ${ }^{25}$.

\section{Discussion and conclusion}

This study has extended to the under-researched context of Italian Fascism the Foucauldian debate of the interrelationship between power and resistance (Ezzamel, 1994; Andrew \& Cahill, 2017; McPhail, 1999; Baños, Domínguez \& Gutiérrez, 2016) and the related role that accounting information can assume. It has explored how the exercise of power by the Fascist government was countered by the University of Ferrara, an organisation which had been traditionally jealous of its independence. The University's opposition led the government to re-focus its initial strategies in the attempt to subjugate the institution and, hence, restrict access to education to working class youth, consistent with the elitist goals of Gentile's reforms. The case of the University demonstrates how the results of strategy implementation can never be $a$ priori known by its proponents due to the complex unravelling of power relations (Miller \& Rose, 1990; Neu \& Heincke, 2004; Foucault, 1988). With power the equivalent of "a way in which certain actions modify others" (Foucault, 1982, p. 188),

\footnotetext{
${ }^{25}$ The fact that becoming a State-subsidised institution was seen as a necessary evil by the University is evident in Visconti's rendition of the official ceremony: "it happened on $28^{\text {th }}$ June 1942, with a rowdy ceremony, while in Africa an ephemeral victory exalted the souls of the Fascists, which made them extremely violent, ministers, party secretaries, hierarchs in boots and medals stormed the University. Professors, swamped with this assault, literarily stayed on the sidelines in their gowns, as if the celebration was not their business" (Visconti, 1950, p. 213).
} 
power and resistance become "two sides of the same coin" (Baños, Domínguez \& Gutiérrez, 2016, p. 476) whereby there will be no individual or group who is able to control the entire power network (Foucault, 1978). Power relationships, of which freedom and, hence, the possibility of resistance are essential elements (Foucault, 1982, 2008), can only be understood by looking at how the subjects involved in the power struggle employ different strategies over time to seek to influence each other's action to achieve their goals.

The threats to the University of Ferrara at the time when Italy was under Fascist rule have revealed how accounting practices and funding policies were used in the implementation of a government programme which sought to make the University an integral part of the Fascist State, without formally limiting its autonomy as a Free University. The University's struggle to remain independent showed that the unravelling of a power relation and the outcome of a power struggle is never obvious or simply the result of a straightforward political calculation, not even in totalitarian States where the balance of power is obviously in favour of the party which governs. The government did not act directly to repress the independence of the University, action which would very likely have been openly resisted by this traditionally free institution. Instead, it starved the University of funds and made visible by the means of accounting information how it needed government support. Funding policies became a technology 
of government used to change the behaviour of the University, to subdue it (Neu, 2000, p. 181), the effect of which was made even more visible and powerful by the means of accounting (Hopwood, 1990). Accounting practices and funding policies were therefore key in turning the ideological priorities of the totalitarian State into practice by making it impossible for the University to resist, thereby enabling the government to structure the organisation's field of action (Foucault, 1982, p. 790).

With Gentile's reform the Fascists sought to implement their vision of the State whereby the education system would play a central role in the creation of a new ruling elite committed to the priorities of the regime. In the achievement of this aim, the State showed that it was not prepared to compromise. As a result, it sought to close the incomplete Faculty of Medicine of the University of Ferrara. This decision, which involved the creation of clear boundaries to the institution's freedom, was justified by reference to a discourse of financial sustainability and backed by an extensive use of accounting techniques. In the first stage of the power struggle the Ministry sought to disguise its attempt to interfere in the activity of the University by portraying this intervention as a rational response to technical problems (Covaleski \& Dirsmith, 1988). This made its actions look disinterested and, hence, more easily acceptable by the University, its supporters and the community of Ferrara (Pfeffer, 1981, p. 184). The University replied by deploying counter-accounts that sought to expose the arbitrariness 
of the Ministry's calculations and secure additional support from local institutions which had traditionally supported the organisation.

Unexpected resistance from the University meant that the government had to re-adjust its power strategy (Foucault, 1982) if the goal of subduing the University was to be achieved. Accordingly, the government took advantage of the debilitating effects of Gentile's reform on the University, including a decrease in student matriculation and related revenue from fees and increased personnel expenses. Again, the University sought to address the situation by mobilising its local network when local funders were prepared to increase their contribution. In response, the government sought to weaken the link between the University and its funders by generating a high financial stress for the organisation which was reflected in the inability of the local funders to keep up their payments. At the same time, the University had to accept the creation of a new degree programme which was consistent with Fascist priorities and would have provided it with vital funds. The government sought to use accounting to legitimise its intervention in the University (Moll \& Hoque, 2011; Berland \& Chiapello, 2009) and make visible the benefits of government funding. New accounting reports required from the University after its new degree was introduced were meant to ensure that the funds provided by the State were not used for other faculties or degree programmes and to make teaching programmes and outcomes visible. This meant that the State was starting 
to be able to direct the activity of the University with certainty of its conduct (Foucault, 1982). This new strategy allowed for no possibility for the University to re-appropriate accounting to pursue its rhetoric of self-sufficiency.

After the government reduced its financial support and called for further investments by the University, the bond between the University and its local supporters reached breaking point when they became unable to sustain the high level of funding needed by the organisation. This made the organisation more vulnerable and thus prepared to surrender its independence. Consistent with what had been done for the degree programme in 'Science of Corporations and Trade Unions', accounting ensured that government funding remained dedicated to specific purposes and provided information on teaching programmes and outcomes. This made obvious the difference between selffunded faculties, those of Science and Law, and the government-funded Faculty of Medicine, when Medicine had access to ample resources. This in turn helped the State to clearly "block [the] field of relations of power" and to "prevent all reversibility of movement" (Foucault, 1988, p. 3) for now the University could only choose to cooperate with the government. So effective were the strategies implemented by the State that not only was it able to dominate the University, it did so without having to bear the full cost of funding the organisation. The University finally came under full control by the State in 1935, although it remained a Free University for another seven 
years. The government was therefore able to make it a compliant subject, seeming to preserve the appearance of independence at the same time.

This study has documented the implementation of a governmental programme (Miller, 2001) as a process by emphasising the complex interrelation of power and resistance and the shifting tactics, among which accounting was important, employed by the actors in the power network (Foucault, 1978). The possibility of resistance and reappropriation of discourses by other subjects who are part of the power relationship means that sub-optimal results may be the outcome of the exercise of power, or that the strategies of those who seek power need to be adjusted in order to achieve the intended goals. Tactics become "connected to one another, attracting and propagating one another $[\ldots]$ by forming comprehensive systems" (Foucault, 1978, p. 95), the final outcome of which is not easily predictable. The outcome of the struggle cannot be $a$ priori known, even when carefully studied strategies are enacted (McKinlay \& Pezet, 2018; Miller \& Rose, 1990; Neu \& Heicke, 2004). Therefore, the study of accounting in the implementation of political programmes requires a careful analysis of its shifting role resulting from the actions of networks of power and the unavoidable exercise of resistance which may cause a change in the way accounting is used or understood. Accounting can support different and conflicting purposes and play a variety of roles. As shown by the case of the University of Ferrara, it can be used for disguising the 
purpose of political action, demonstrating the achievement of financial stability and self-sufficiency, providing legitimacy or ensuring the use of resources consistent with the aims of those who exercise power.

The paper has also implications for contemporary society, in particular with regards to the imperative of protecting academic freedom. Although the University of Ferrara fought a desperate battle against a totalitarian regime, academic freedom cannot be taken for granted with the advent and development of liberal democracies. Said (1994, p. 61) reminds us that:

in spending a lot of time worrying about the restrictions on thought and intellectual freedom under totalitarian systems of government we have not been as fastidious in considering the threats to the individual intellectual of a system that rewards intellectual conformity, as well as willing participation in goals that have been set not by science but the government.

Even in modern liberal societies, governments often call on intellectuals to provide apparently neutral, qualified legitimacy for their actions (Brenda, 1980). Academics can therefore be the subject of considerable pressure from government, administrators and funders to further the political and commercial agendas of these bodies, or at least not to interfere by resisting (Ginsberg, 2011). Contrary to the expectations of those in power, intellectuals, and most especially academics, who can play an important role in shaping new generations' understandings of reality, are called to 
raise embarrassing questions, to confront orthodoxy and dogma (rather than to produce them), to be someone who cannot easily be co-opted by governments or corporations, and whose raison d'être is to represent all those people and issues that are routinely forgotten or swept under the rug (Said, 1994, p. 9).

Academic freedom needs to be protected and nurtured because the development of a modern, dynamic society depends on the constant flow of new ideas. It is "of transcendent value to all of us and not merely to the teachers concerned" (Warren, quoted in Ginsberg, 2011, p. 132).

Future research could provide further insights into the interrelationship between power and resistance and the role accounting can play in this process. More should also be known of the role of accounting in totalitarian regimes, most especially as a tool to exert control and create and reinforce power relations with the aim to shape the will of people according to the plans of governments. Other universities or institutions could be investigated, most especially in Fascist Italy or Nazi Germany, to appreciate if and how accounting took a role in government plans to make them a fully functional part of the State. 


\section{Primary Sources}

\section{Historical Archive of the University of Ferrara (AUF)}

Letter of the Minister of Education to the Rector, $23^{\text {rd }}$ August 1924.

Letter of the Minister of Education to the Rector, $29^{\text {th }}$ March 1926.

Letter of the Minister of Corporations to the Rector, $22^{\text {nd }}$ December 1927.

Letter of the Minister of Education to the Rector, $26^{\text {th }}$ March 1929.

Letter of the Ministry of Corporations to the Rector, $18^{\text {th }}$ July 1929.

Letter of the Minister of Corporations to the Rector, $4^{\text {th }}$ October 1929.

Letter of the Ministry of Education to the Rector, $3^{\text {rd }}$ September 1937.

Letter of the Minister of Education to the Rector, $19^{\text {th }}$ July 1940.

Letter of the Minister of Education to the Rector, $15^{\text {th }}$ April 1941.

Letter of the Minister of Education to the Rector, $26^{\text {th }}$ June 1941.

Letter of the Ministry of Education to the Rector, $19^{\text {th }}$ July 1941.

Letter of the Rector to the Municipality of Turin, $10^{\text {th }}$ December 1941.

Series $10.1,25$, Minutes of the Council of the University, $24^{\text {th }}$ September $1913-1^{\text {st }}$ December 1924.

Series 16.1, 55, Minutes of the Board of Directors, $14^{\text {th }}$ April $1925-13^{\text {th }}$ July 1933.

Series 16.1, 56, Minutes of the Board of Directors, $13^{\text {th }}$ July $1934-23^{\text {rd }}$ July 1942.

Series 65.6, Budgets, 1926 - 1942.

Series 65.7, Financial Statements, 1923 - 1942.

Statute, 1924.

Yearbooks, 1922-1943.

Historical Archive of the Municipality of Ferrara (AMF)

Series 21, Budgets and commentaries, $1927-1944$.

Ariostea Library $(A L)$

Relazione intorno all'attuazione del Decreto Ministeriale 14 Febbraio 1860, VS 948. 
Historical Archive of the Senate (AS)

Senato del Regno, $3^{\text {rd }}$ June 1927.

Senato del Regno, 27 $7^{\text {th }}$ November 1922.

Senato del Regno, Documenti, Legislatura XXVII, $1^{\text {st }}$ session, $18^{\text {th }}$ May 1927.

\section{References}

Andrew, J., \& Cahill, D. (2017). Rationalising and resisting neoliberalism: The uneven geography of costs. Critical Perspectives on Accounting, 45, 12-28.

Baños, J., Gutierrez, F., Álvarez-Dardet, C., \& Carrasco, F. (2005). Govern(mentality) and accounting: The influence of different Enlightenment discourses in two Spanish cases (1761-1777). Abacus, 41(2), 181-210.

Baños, J., Domínguez, M., \& Gutiérrez, F. (2016). Accounting in the dynamic of discourses: The rise and fall of the Spanish system of intendants, 1718-1724. Accounting History, 21(4), 472-488.

Barbagli, M. (1982). Educating for unemployment. Politics, labor markets, and the school system - Italy, 1859-1973. New York: Columbia University Press.

Berland, N., \& Chiapello, E. (2009). Criticisms of capitalism, budgeting and the double enrolment: Budgetary control rhetoric and social reform in France in the 1930s and 1950s. Accounting, Organizations and Society, 34(1), 28-57.

Bigoni, M., \& Funnell, W. (2015). Ancestors of governmentality. Accounting and pastoral power in the $15^{\text {th }}$ century. Critical Perspectives on Accounting, 27, 160176.

Brenda, J. (1980). The treason of the intellectuals. London: Norton.

Burrell, G. (1988). Modernism, post modernism and organizational analysis 2: The contribution of Michel Foucault. Organization Studies, 9(2), 221-235.

Cazzetta, G. (2004). La Facoltà di giurisprudenza nella Libera Università di Ferrara (1860-1942). Annali di storia delle università italiane, 8, 183-211.

Charnitzky, J. (1996). Fascismo e scuola. La politica scolastica del regime, 1922-1943. Firenze: La Nuova Italia.

Ciampi, G., \& Santangeli, C. (1994). Il consiglio superiore della pubblica istruzione 1847-1928. Roma: Ministero per i Beni Culturali e Ambientali.

Cinquini, L. (2005). Corporativismo fascista e studi aziendali negli anni Trenta: Riflessi nello sviluppo delle dottrine economico-aziendali. In Società Italiana di Storia della Ragioneria (Ed.), Atti del VII Convegno Nazionale della Società Italiana di Storia della Ragioneria (Vol. 1, pp. 293-336). Roma: Rirea. 
Cinquini, L. (2007). Corporative economy and accounting in Italy during the thirties: Exploring the relations between a totalitarian ideology and business studies. Accounting, Business and Financial History, 17(2), 209-240.

Cinquini, L., Giannetti, R., \& Tenucci, A. (2016). The making of uniform costing in a war economy: The case of the Uniconti Commission in Fascist Italy. Accounting History, 21(4), 445-471.

Covaleski, M. A., \& Dirsmith, M. W. (1988). The use of budgetary symbols in the political arena: An historically informed field study. Accounting, Organizations and Society, 13(1), 1-24.

De Grand, A. (1994). Italian Fascism: its origins and development. Lincoln: University of Nebraska Press.

Ezzamel, M. (1994). Organizational change and accounting: Understanding the budgeting system in its organizational context. Organization Studies, 15(2), 213240.

Ezzamel, M., Willmott, H. \& Worthington, F. (2001). Power, control and resistance in 'the factory that time forgot'. Journal of Management Studies, 38(8), 10531079.

Ezzamel, M., Willmott, H. \& Worthington, F. (2008). Manufacturing shareholder value: The role of accounting in organizational transformation. Accounting, Organizations and Society, 33(2/3), 107-140.

Farjaudon, A. L., \& Morales, J. (2013). In search of consensus: The role of accounting in the definition and reproduction of dominant interests. Critical Perspectives on Accounting, 24(2), 154-171.

Foucault, M. (1978). The history of sexuality. Volume I: an introduction. New York: Pantheon Books.

Foucault, M. (1980). The eye of power. In C. Gordon (Ed.), Power/knowledge. Selected interviews and other writings 1972-1977 (pp. 146-165). New York: Pantheon Books.

Foucault, M. (1982). The subject and power. Critical Inquiry, 8(4), 777-795.

Foucault, M., (1988). The ethic of care for the self as a practice of freedom. In J. Bernauer \& D. Rasmussen (Eds.), The final Foucault (pp. 1-20). Cambridge: MIT Press.

Foucault, M. (1995). Discipline and punish. The birth of the prison. New York: Vintage Books.

Foucault, M. (2007). Security, population, territory. Lectures at the Collège de France (1977-1978). New York: Palgrave Macmillan,

Foucault, M. (2008). The birth of biopolitics. Lectures at the Collège de France (19781979). New York: Palgrave Macmillan. 
Funnell, W., Antonelli, V., D’Alessio, R., \& Rossi, R. (2017). Accounting for madness: The "Real Casa dei Matti" of Palermo 1824-1860. Accounting, Auditing \& Accountability Journal, 30(5), 1111-1141.

Gentile, G. (1924). La riforma della scuola: Discorso tenuto il 15 novembre 1923 al Consiglio Superiore della Pubblica Istruzione. Bari: Laterza.

Gentile, G. (1928). The philosophic basis of fascism. Foreign Affairs, 6(2): 290-304.

Gentile, G. (2004). Discorsi Parlamentari. Bologna: Il Mulino.

Ginsberg, B. (2011). Fall of the faculty: The rise of the all-administrative university and why it matters. Oxford: Oxford University Press.

Giuntella, M. C. (1992). Autonomia e nazionalizzazione dell'Università. Il fascismo e l'inquadramento degli Atenei. Roma: Edizioni Studiorum.

Gordon, C. (1980). Afterword. In C. Gordon (Ed.), Power/knowledge. Selected interviews and other writings 1972-1977 (pp. 229-258). New York: Pantheon Books.

Gregor, A. J. (1974). L'ideologia del Fascismo. Il fondamento rezionale del totalitarismo. Milano: Edizioni Del Borghese.

Grendler, P. (2002). The universities of the Italian renaissance. Baltimore: Johns Hopkins University Press.

Heller, K. J. (1996). Power, subjectification and resistance in Foucault. SubStance, 25(1), 78-110.

Hopwood, A. (1990). Accounting and organisation change. Accounting Auditing \& Accountability Journal, 3(1), 7-17.

Hopwood, A. (1992). Accounting calculation and the shifting sphere of the economic. European Accounting Review, 1(1), 123-143.

Knights, D. \& Collinson, D. (1987). Disciplining the shopfloor: A comparison of the disciplinary effects of managerial psychology and financial accounting. Accounting, Organizations and Society, 12(5), 457-477.

Kosmala, K., \& McKernan, J. F. (2011). From the care of the self to the care of the other: Neglected aspects of Foucault's late work. Accounting Auditing \& Accountability Journal, 24(3), 377-402.

Lyttleton, A. (1973). The seizure of power: Fascism in Italy 1919-1929. Bath: The Pitman Press.

Madonna, S., Maran, L., \& Cestari, G. (2014). The 1771 and 1824 reforms of the University of Ferrara: A Foucauldian analysis of papal interests. Accounting History, 19(4), 507-532.

Maran. L., Bracci, E., \& Funnell, W. (2015). Accounting and the management of power: Napoleon's occupation of the commune of Ferrara (1796-1799). Critical Perspectives on Accounting, 34, 60-78. 
Markus, M. L., \& Pfeffer, J. (1983). Power and the design and implementation of accounting and control systems. Accounting, Organizations and Society, 8(2/3), 205-218.

McKinlay, A., Carter, C., Pezet, E., \& Clegg, S. (2010). Using Foucault to make strategy. Accounting, Auditing \& Accountability Journal, 23(8), 1012-1031.

McKinlay, A., \& Pezet, E. (2018). Foucault, governmentality, strategy: From the ear of the sovereign to the multitude. Critical Perspectives on Accounting, 53, 57-68.

McPhail, K. (1999). The threat of ethical accountants: An application of Foucault's concept of ethics to accounting education and some thoughts on ethically educating for the other. Critical Perspectives on Accounting, 10(6), 833-866.

Miller, P. (2001). Governing by numbers: Why calculative practices matter. Social Research, 68(2), 379-396.

Miller, P., \& O'Leary, T. (1987). Accounting and the construction of the governable person. Accounting, Organizations and Society, 12(3), 235-265.

Miller, P., \& Rose, N. (1990). Governing economic life. Economy and Society, 19(1), 131.

Moll, J., \& Hoque, Z. (2011). Budgeting for legitimacy: The case of an Australian University. Accounting, Organizations and Society, 36(2), 86-101.

Morgan, P. (1995). Italian Fascism, 1919-1945. Houndmills: Macmillan.

Mussolini, B. (1956a). Adagio. In E. Susmel \& D. Susmel (Eds.), Opera Omnia di Benito Mussolini (Vol. 18, pp. 409-410). Firenze: La Fenice.

Mussolini, B., (1956b). Telegrammi. In E. Susmel \& D. Susmel (Eds.), Opera Omnia di Benito Mussolini (Vol. 20, pp. 358-384). Firenze: La Fenice.

Mussolini, B., \& Gentile, G. (1961). Dottrina del fascismo. In E. Susmel \& D. Susmel (Eds.), Opera Omnia di Benito Mussolini (Vol. 34, pp. 122-138). Firenze: La Fenice.

Neu, D. (2000). "Presents" for the "Indians": Land, colonialism and accounting in Canada. Accounting, Organizations and Society, 25(2), 163-184.

Neu D. (2006). Accounting for public space. Accounting, Organizations and Society, 31(4-5), 391-414.

Neu, D., \& Heincke, M. (2004). The subaltern speaks: Financial relations and the limits of governmentality. Critical Perspectives on Accounting, 15(1), 179-206.

Pepe, L. (2003). Copernico e lo studio di Ferrara. Bologna: Clueb.

Peters, K. (2001). When reform comes into play: Budgeting as negotiations between administrations. Accounting, Organizations and Society, 26(6), 521-539.

Pfeffer, J. (1981). Power in organizations. Marshfield: Pitman.

Riccaboni, A., Giovannoni, E., Giorgi, A., \& Moscardelli, S. (2006). Accounting and power: Evidence from the fourteenth century, Accounting History, 11(1), 41-62. 
Recchi, E. (2007). Italy: Expansion, reform, and social inequality in higher education. In Y. Shavit, R. Arum \& A. Gamoran (Eds.), Stratification in higher education: A comparative study (pp. 400-423). Stanford: Stanford University Press.

Rose, N., \& Miller, P. (1992). Political power beyond the State: Problematic of government. British Journal of Sociology, 43(2), 173-205.

Said, E. W. (1994). Representations of the intellectual. The 1993 Reith lectures. London: Vintage Books.

Sargiacomo, M. (2008). Accounting and the "Art of Government": Margaret of Austria in Abruzzo (1539-86). European Accounting Review, 17(4), 667-695.

Sargiacomo, M., Ianni, L., D'Andreamatteo, A., \& D'Amico, L. (2016). Accounting and the government of the agricultural economy: Arrigo Serpieri and the Reclamation Consortia. Accounting History Review, 26(3), 307-331.

Visconti, A. (1950). La storia dell'Università di Ferrara. Bologna: Zanichelli.

Yayla, H. E. (2011). Operating regimes of the government: Accounting and accountability changes in the Sultan Süleyman Waqf of the Ottoman Empire (The 1826 Experience). Accounting History, 16(1), 5-34. 
Table 1: Number of students of the University of Ferrara and University fees between 1923-1924 and 1927-1928.

\begin{tabular}{|c|c|c|c|}
\hline Academic year & Students & $\begin{array}{c}\text { University fees } \\
\text { collected at the } \\
\text { end of the year } \\
\text { (lire) }\end{array}$ & $\begin{array}{c}\text { Average fees per } \\
\text { student } \\
\text { (lire) }\end{array}$ \\
\hline $\mathbf{1 9 2 3 - 1 9 2 4}$ & 645 & 161,835 & 251 \\
\hline $\mathbf{1 9 2 4 - 1 9 2 5}$ & 508 & 114,795 & 226 \\
\hline $\mathbf{1 9 2 5 - 1 9 2 6}$ & 204 & 117,890 & 578 \\
\hline $\mathbf{1 9 2 6 - 1 9 2 7}$ & 198 & 120,580 & 609 \\
\hline $\mathbf{1 9 2 7 - 1 9 2 8}$ & 216 & 103,305 & 478 \\
\hline
\end{tabular}

Source: AUF, Yearbooks, 1923-1928; AUF, Series 65.7.

Table 2: The funding structure of the University of Ferrara between 1923-1924 and 1926-1927.

\begin{tabular}{|c|c|c|c|c|}
\hline $\begin{array}{c}\text { (1) } \\
\text { Academic } \\
\text { year }\end{array}$ & $\begin{array}{c}\text { (2) } \\
\text { Budgeted } \\
\text { contributions } \\
\text { from local } \\
\text { funders } \\
\text { (lire) }\end{array}$ & $\begin{array}{c}\text { Am) } \\
\text { Amount owed } \\
\text { by local } \\
\text { funders for the } \\
\text { current year } \\
\text { (lire) }\end{array}$ & $\begin{array}{c}\text { (4) } \\
\text { Cumulative } \\
\text { amount owed } \\
\text { by local } \\
\text { funders } \\
\text { (lire) }\end{array}$ & $\begin{array}{c}\text { (5) } \\
\text { Profit/Loss } \\
\text { at the end } \\
\text { of the } \\
\text { period } \\
\text { (lire) }\end{array}$ \\
\hline $\mathbf{1 9 2 3 - 1 9 2 4}$ & 127,272 & 19,358 & 20,012 & 130,478 \\
\hline $\mathbf{1 9 2 4 - 1 9 2 5}$ & 342,096 & 26,065 & 26,590 & 54,913 \\
\hline $\mathbf{1 9 2 5 - 1 9 2 6}$ & 342,095 & 41,639 & 42,227 & 29,188 \\
\hline $\mathbf{1 9 2 6 - 1 9 2 7}$ & 352,000 & 45,759 & 64,118 & $-23,703$ \\
\hline
\end{tabular}

Source: AUF, Series 65.6; AUF, Series 65.7. 
Table 3: Funding structure of the University of Ferrara between 1927-1928 and 1930-1931.

\begin{tabular}{|c|c|c|c|c|c|}
\hline $\begin{array}{c}\text { (1) } \\
\text { Academic } \\
\text { year }\end{array}$ & $\begin{array}{c}\text { (2) } \\
\text { Budgeted } \\
\text { contributions } \\
\text { from local } \\
\text { funders } \\
\text { (lire) }\end{array}$ & $\begin{array}{c}\text { Amount owed } \\
\text { by local } \\
\text { funders for } \\
\text { the current } \\
\text { year } \\
\text { (lire) }\end{array}$ & $\begin{array}{c}\mathbf{( 4 )} \\
\text { Cumulative } \\
\text { amount owed } \\
\text { by local } \\
\text { funders } \\
\text { (lire) }\end{array}$ & $\begin{array}{c}\text { (5) } \\
\text { Profit/Loss } \\
\text { at the end } \\
\text { of the } \\
\text { period } \\
\text { (lire) }\end{array}$ & $\begin{array}{c}\text { Government } \\
\text { contribution } \\
\text { (lire) }\end{array}$ \\
\hline $\mathbf{1 9 2 7 - 1 9 2 8}$ & 603,311 & 78,684 & 81,814 & 12,041 & - \\
\hline $\mathbf{1 9 2 8 - 1 9 2 9}$ & 578,291 & 69,754 & 83,935 & 174,045 & 170,000 \\
\hline $\mathbf{1 9 2 9 - 1 9 3 0}$ & 560,281 & 143,428 & 181,069 & 145,971 & 120,000 \\
\hline $\mathbf{1 9 3 0 - 1 9 3 1}$ & 560,281 & 237,109 & 334,689 & 108,738 & 100,000 \\
\hline
\end{tabular}

Source: AUF, Series 65.6; AUF, Series 65.7.

Table 4: Funding structure of the University of Ferrara between 1931-1932 and 1935-1936.

\begin{tabular}{|c|c|c|c|c|c|c|}
\hline $\begin{array}{c}(1) \\
\text { Academic } \\
\text { year }\end{array}$ & $\begin{array}{c}(2) \\
\text { Budgeted } \\
\text { contributions } \\
\text { from local } \\
\text { funders } \\
\text { (lire) }\end{array}$ & $\begin{array}{c}\text { (3) } \\
\text { Amount owed } \\
\text { by local } \\
\text { funders for } \\
\text { the current } \\
\text { year } \\
\text { (lire) }\end{array}$ & $\begin{array}{c}(4) \\
\text { Cumulative } \\
\text { amount owed } \\
\text { by local } \\
\text { funders } \\
\text { (lire) }\end{array}$ & $\begin{array}{c}(5) \\
\text { Bad } \\
\text { debts } \\
\text { (lire) }\end{array}$ & $\begin{array}{c}(6) \\
\text { Profit/Loss } \\
\text { at the end } \\
\text { of the } \\
\text { period } \\
\text { (lire) }\end{array}$ & $\begin{array}{c}(7) \\
\text { Government } \\
\text { contribution } \\
\quad \text { (lire) }\end{array}$ \\
\hline $\begin{array}{c}1931- \\
1932\end{array}$ & 514,931 & 217,560 & 311,349 & 106,473 & $-106,617$ & 60,000 \\
\hline $\begin{array}{l}1932- \\
1933\end{array}$ & 439,931 & 155,014 & 257,705 & & $-29,325$ & 60,000 \\
\hline $\begin{array}{c}1933- \\
1934\end{array}$ & 439,931 & 169,971 & 255,327 & 30,000 & $-38,574$ & 60,000 \\
\hline $\begin{array}{l}1934- \\
1935 \\
\end{array}$ & 430,667 & 108,498 & 213,659 & & 26,465 & 60,000 \\
\hline $\begin{array}{l}1935- \\
1936 \\
\end{array}$ & 430,697 & 54,718 & 96,329 & 108,102 & $-149,180$ & 60,000 \\
\hline
\end{tabular}

Source: AUF, Series 65.6; AUF, Series 65.7. 
Table 5: Funding structure of the University of Ferrara between 1936-1937 and 1941-1942.

\begin{tabular}{|c|c|c|c|c|c|c|}
\hline $\begin{array}{c}(1) \\
\text { Academic } \\
\text { year }\end{array}$ & $\begin{array}{c}\text { (2) } \\
\text { Budgeted } \\
\text { contributions } \\
\text { from local } \\
\text { funders } \\
\text { (lire) }\end{array}$ & $\begin{array}{c}\text { (3) } \\
\text { Amount owed by } \\
\text { local funders for } \\
\text { the current year } \\
\text { (lire) }\end{array}$ & $\begin{array}{c}\text { (4) } \\
\text { Cumulative } \\
\text { amount owed by } \\
\text { local funders } \\
\text { (lire) }\end{array}$ & $\begin{array}{c}(5) \\
\text { Bad } \\
\text { debts } \\
\text { (lire) }\end{array}$ & $\begin{array}{c}\text { (6) } \\
\text { Profit/Loss } \\
\text { at the end } \\
\text { of the } \\
\text { period } \\
\text { (lire) }\end{array}$ & $\begin{array}{c}(7) \\
\text { Government } \\
\text { contribution } \\
\text { (lire) }\end{array}$ \\
\hline $\begin{array}{c}1936- \\
1937\end{array}$ & 410,697 & 55,812 & 72,200 & 20,665 & $-16,663$ & 293,333 \\
\hline $\begin{array}{c}1937- \\
1938\end{array}$ & 660,185 & 304,662 & 365,196 & & 305,014 & 400,000 \\
\hline $\begin{array}{c}1938- \\
1939\end{array}$ & 649,188 & 129,055 & 778,046 & & 396,038 & 400,000 \\
\hline $\begin{array}{c}1939- \\
1940\end{array}$ & 643,688 & 274,859 & $1,179,321$ & & 420,224 & 400,000 \\
\hline $\begin{array}{c}1940- \\
1941\end{array}$ & 643,688 & 268,751 & $1,313,276$ & 96,433 & 367,065 & 400,000 \\
\hline $\begin{array}{c}1941- \\
1942\end{array}$ & 643,688 & 265,200 & $1,159,317$ & & 332,488 & 400,000 \\
\hline
\end{tabular}

Source: AUF, Series 65.6; AUF, Series 65.7. 